$36.5(4)^{\circ}$. The planes of the benzene rings of the sulfonilamide moieties in molecules $A$ and $B$ are inclined with respect to the planes of the pyrazole rings at $53.5(4)$ and $75.9(3)^{\circ}$ respectively. The planes of benzene rings and the pyrazole rings in molecules $A$ and $B$ are rotated with respect to each other by 46.9 (4) and $69.1(4)^{\circ}$ respectively. As has been observed in other sulfonamides (Haridas \& Singh, 1987), both molecules adopt gauche conformations about the $\mathrm{S}-\mathrm{N}$ bonds with torsion angles of $-73.7(8)$ and $94.0(8)^{\circ}$ respectively. The torsion angle $\mathrm{S}(8)-\mathrm{N}(11)-\mathrm{C}(12)-\mathrm{N}(16)$ is $-107.1(9)^{\circ}$ in molecule $A$ while the corresponding angle in $B$ is $-119.7(8)^{\circ}$. As has been described above, it is clear that the two crystallographically independent molecules have identical molecular dimensions but substantially different conformations. This shows that sulfaphenazole is a flexible molecule capable of undergoing conformational change as a result of variation in the intermolecular interactions while the molecular dimensions remain unchanged.

Molecular packing and hydrogen bonding. The crystal structure as seen down the $b$ axis is shown in Fig. 2 . The molecules are packed rather compactly and form hydrogen-bonded helices along the screw axes. These helices are formed as a result of $\mathrm{N}-\mathrm{H} \cdots \mathrm{N}$-type hydrogen bonds involving the imino nitrogen atoms $\mathrm{N}(11)$ and $\mathrm{N}(33)$ as proton donors and the heteronitrogen atoms $N(37)$ and $N(15)$ of the five-membered rings as the corresponding acceptors. The interior of the helix is filled with screw-related benzene rings. The sulfonilamide moieties are disposed outwardly from the helix and provide the interhelix linkage through hydrogen bonds and van der Waals forces. The amino nitrogen atoms $\mathrm{N}(7)$ and $\mathrm{N}(29)$ form hydrogen bonds ,with $O(9)$ and $O(10)$ respectively. The sulfonyl oxygen atoms $\mathrm{O}(31)$ and $\mathrm{O}(32)$ of molecule $B$ form van der Waals contacts with $\mathrm{C}(18), \mathrm{C}(19)$ and $\mathrm{C}(14), \mathrm{N}(15)$ respectively. It is observed that the two crystallographically independent molecules $A$ and $B$ are involved in different types of intermolecular interactions and hence exhibit conformational variability, thus showing the flexible nature of the sulfaphenazole molecule. This might mean that this molecule is adaptable to the variable stereochemical receptor site.

The authors gratefully acknowledge financial support from ICMR, New Delhi.

\section{References}

ABrahams, S. C. (1955). Acta Cryst. 8, 661-691.

BARTELL, L. S. (1962). Tetrahedron, 17, 17.

Bock, L., Miller, G. H., Schaper, K. J. \& SeYdel, J. K. (1974). J. Med. Chem. 17, 23-28.

Cromer, D. T. \& MANN, J. B. (1968). Acta Cryst. A24, 321-324.

CRuiCKSHANK, D. W. J. (1961a). In Computing Methods and the Phase Problem in X-ray Crystal Structure Analysis, edited by R. PePInsky, pp. 32-62. Oxford: Pergamon.

Cruickshank, D. W. J. (1961b). J. Chem. Soc. pp. 5486-5504.

HARIDAS, M. \& Singh, T. P. (1986). Ind. J. Chem. 25A, 707-713.

HARIDAS, M. \& Singh, T. P. (1987). Ind. J. Biochem. Biophys. In the press.

International Tables for X-ray Crystallography (1962). Vol. II, pp. 202-203. Birmingham: Kynoch Press. (Present distributor D. Reidel, Dordrecht.)

Main, P., Fiske, S. J., Hull, S. E., Lessinger, L., Germain, G. DeClercQ, J.-P. \& WoOlfSon, M. M. (1980). MULTAN80. A System of Computer Programs for the Automatic Solution of Crystal Structures from X-ray Diffraction Data. Univs. of York, England, and Louvain, Belgium.

PAuling, L. (1960). The Nature of the Chemical Bond. Ithaca, New York: Cornell Univ. Press.

Sass, R. L. (1960). Acta Cryst. 13, 320-324.

Schomaker, V. \& Stevenson, D. P. (1941). J. Am. Chem. Soc. $63,39-40$.

Shiono, R. (1968/1971). SFLS. Tech. Reps. 48 and 49. Crystallography Laboratory, Univ. of Pittsburgh.

Stewart, R. F., Davidson, E. R. \& Simpson, W. T. (1965). J. Chem. Phys. 42, 3175-3187.

Acta Cryst. (1987). C43, 1134-1138

\title{
Structure and Molecular-Packing Analysis of a Heptofuranosoimidazolidine-2-thione*
}

\author{
By M. D. Estrada, A. Conde ANd R. MÁrquez \\ Departamento de Física del Estado Sólido, Facultad de Física, Universidad de Sevilla, Spain
}

(Received 13 June 1986; accepted 6 January 1987)

\begin{abstract}
Bromophenyl)-3-ethyl-(3,5,6,7-tetra-Oacetyl-1,2-dideoxy-D-glycero- $\beta$-D-talo-heptofuranoso)-

\footnotetext{
* IUPAC name: 1-\{6-acetoxy-3-bromophenyl-2-thioxo-2,3,3a,
} 5,6,6a-tetrahydro- $1 H$-furo[2,3- $d]$ imidazol-5-yl $\}$ propane-1,2,3-triyl triacetate.
\end{abstract}

[2,1-d] imidazolidine-2-thione, $\mathrm{C}_{24} \mathrm{H}_{29} \mathrm{BrN}_{2} \mathrm{O}_{9} \mathrm{~S}, \quad M_{r}=$ 601.46, orthorhombic, $\quad P 22_{1} 2_{1}, \quad a=15.634$ (3), $b=22.749(6), \quad c=7.714(2) \AA, \quad V=2743(1) \AA^{3}$, $Z=4, \quad D_{x}=1.46 \mathrm{Mg} \mathrm{m}^{-3}, \quad \lambda(\mathrm{Mo} K \alpha)=0.7107 \AA$, $\mu=1.60 \mathrm{~mm}^{-1}, \quad F(000)=1240$, room temperature, final $w R=0.052$ for 1643 observed reflexions.

(c) 1987 International Union of Crystallography 
The sugar ring adopts the ${ }^{4} E$ conformation and the dihedral angle in the bicycle system is $71.5(7)^{\circ}$. The crystal cohesion is mainly due to van der Waals interactions but some $\mathrm{C}-\mathrm{H}$... O intermolecular contacts should be considered as weak hydrogen bonds. The lattice energy was computed in the atom-atom approach using van der Waals potential functions. The Coulombic term makes an important contribution to the lattice energy but no significant changes in structural parameters are obtained from its consideration.

Introduction. The structure determination of the title compound (I) was undertaken as part of a research project in this laboratory involving glucimidazoles and imidazole $C$-nucleosides. Recently, some compounds derived from 2-(alkylamino)-2-deoxyheptoses and 2(alkylamino)-2-deoxyhexoses, prepared in the Organic Chemistry Department of the University of Extremadura, have been reported (e.g. Estrada, Conde \& Márquez, 1983, 1984, 1986; Conde, Millán, Conde \& Márquez, 1985a, 1985b) and in this paper we report the structural analysis of a tetra-O-acetyl derivative. The aim of these studies is to establish the conformational details of these molecules in the solid state. The application of aminonitrile synthesis to the preparation of the new 2-(ethylamino)-2-deoxyheptose having $\mathrm{D}$ glycero-D-talo configuration and its reaction with 4-bromophenyl isothiocyanate to afford the title compound has been reported elsewhere (Galbis-Pérez, Palacios-Albarrán, Jiménez-Requejo \& AvalosGonzález, 1984). Its chemical nature was established from elemental analysis and spectroscopic IR and ${ }^{1} \mathrm{H}$ NMR data.

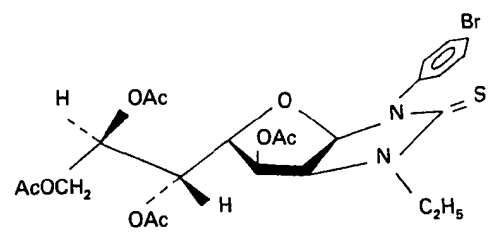

(I)

Experimental. Single crystals in the form of colourless needles elongated along [001]. Crystal $0.20 \times 0.30 \times$ $0.40 \mathrm{~mm}$. The poor quality of the crystals made selection difficult and should limit the accuracy of diffraction data. Unit-cell parameters from 25 reflexions $4<\theta<8^{\circ}$. Enraf-Nonius CAD -4 diffractometer, graphite monochromator, $2<\theta<30^{\circ}, 0 \leq h \leq 22$, $0 \leq k \leq 32,0 \leq l \leq 10, \omega-2 \theta$ scan mode. Two standard reflexions $(360, \overline{3} \overline{6})$, variation in intensity $<2 \%$ of the mean value. 2703 independent reflexions measured, 1060 unobserved $[I<2 \sigma(I)]$. Lorentz and polarization correction, no corrections for absorption or extinction; Patterson function and heavy-atom method with initial set of phases based on $\mathrm{Br}$ and $\mathrm{S}$ atom positions. Full-matrix least-squares refinement on $F$, anisotropic. The enantiomorphic form was established in agreement with that defined by reference to the sugar moiety (Galbis-Pérez et al., 1984). H-atom coordinates calculated at expected geometry $(\mathrm{C}-\mathrm{H}$ $=1.08 \AA$ ); isotropic temperature factor $B=4.0 \AA^{2}$ for $\mathrm{H}$ atoms. Further least-squares refinement keeping the $\mathrm{H}$ atoms in calculated positions and anomalousdispersion correction for $\mathrm{Br}$ and $\mathrm{S}$ atomic scattering factors (International Tables for $X$-ray Crystallography, 1974) reduced $w R$ to $0.052(R=0.081)$; weighting scheme based on statistical count criterion $\left(w=1 / \sigma^{2}\right) .(\Delta / \sigma)<0.01, S=0.96,334$ refined parameters. Number of reflexions/number of parameters $=4.92$. Final difference synthesis showed $0.30>$

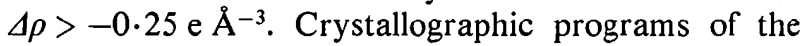
$X R A Y 76$ system (Stewart, Machin, Dickinson, Ammon, Heck \& Flack, 1976).

Discussion. Fractional atomic coordinates and equivalent isotropic temperature factors (Hamilton, 1959) for non-hydrogen atoms are listed in Table $1 .{ }^{*}$ Molecular conformation and atom labelling are illustrated in Fig. 1. Bond lengths and angles involving non-hydrogen atoms are given in Table 2.

\section{Molecular geometry}

Bond distances and angles in the imidazolidine ring agree with the mean values reported for analogous glycofuranosoimidazolidine-2-thione compounds (Estrada, Conde \& Márquez, 1983, 1984, 1986; Conde, Millán, Conde \& Márquez, 1985a,b). The S-C bond length of 1.688 (17) $\AA$ and those observed for $\mathrm{N}(1)-\mathrm{C}(1)=1.35(2)$ and $\mathrm{N}(2)-\mathrm{C}(1)=1.34(2) \AA$ indicate the contribution of the canonical resonance forms of the thiourea system:

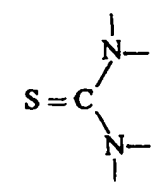

(a)<smiles>CN(C)C(S)=[N+](C)C</smiles>

(b)<smiles>CN(C)C(S)=[N+](C)C</smiles>

(c)
This compound does not show asymmetry of the endocyclic N-C bonds, in agreement with results recently reported (Estrada, Conde \& Márquez, 1986). This asymmetry, observed in other analogous compounds, was attributed to the different substituents at the two $\mathrm{N}$ atoms. The imidazolidine ring is planar $\left[\Sigma(\Delta / \sigma)^{2}=8 \cdot 56, \chi^{2}\right.$ at $\left.95 \%=5.99\right]$. The phenyl ring

\footnotetext{
${ }^{*}$ Lists of structure factors, anisotropic thermal parameters and $\mathrm{H}$-atom coordinates have been deposited with the British Library Document Supply Centre as Supplementary Publication No. SUP 43703 (14 pp.). Copies may be obtained through The Executive Secretary, International Union of Crystallography, 5 Abbey Square, Chester CH1 2HU, England.
} 
forms a dihedral angle of $112.3(6)^{\circ}$ with the imidazolidine ring and this value, which approaches the $90^{\circ}$ value corresponding to a minimum of the intramolecular energy, indicates a significant contribution of intramolecular (phenyl-imidazolidine) potential

Table 1. Atomic coordinates and equivalent isotropic thermal parameters $\left(\AA^{2} \times 10^{3}\right)$

$$
U_{\mathrm{eq}}=\frac{1}{3} \sum_{i} \sum_{j} a_{i}^{*} a_{j}^{*} a_{i} \cdot a_{j} \cos \left(\mathbf{a}_{i} \cdot \mathbf{a}_{j}\right) .
$$

\begin{tabular}{llr}
\multicolumn{1}{c}{$x$} & \multicolumn{1}{c}{$y$} & \multicolumn{1}{c}{$z$} \\
$0.8395(1)$ & $0.5433(1)$ & \multicolumn{1}{c}{$0.4748(3)$} \\
$0.6806(4)$ & $0.2596(2)$ & $0.6382(7)$ \\
$0.5866(6)$ & $0.3343(4)$ & $0.0864(15)$ \\
$0.4614(6)$ & $0.2078(4)$ & $0.1757(16)$ \\
$0.4416(7)$ & $0.3301(5)$ & $-0.1437(15)$ \\
$0.4317(8)$ & $0.4118(5)$ & $0.2567(15)$ \\
$0.2800(7)$ & $0.4063(5)$ & $0.0338(17)$ \\
$0.4647(9)$ & $0.1420(5)$ & $-0.0376(20)$ \\
$0.3380(8)$ & $0.2642(5)$ & $-0.1438(17)$ \\
$0.4770(10)$ & $0.5043(6)$ & $0.2345(28)$ \\
$0.2517(8)$ & $0.4784(5)$ & $0.2225(20)$ \\
$0.6797(8)$ & $0.3060(5)$ & $0.3189(17)$ \\
$0.6208(8)$ & $0.2180(5)$ & $0.3327(17)$ \\
$0.6571(12)$ & $0.2611(7)$ & $0.4247(21)$ \\
$0.6537(11)$ & $0.2969(6)$ & $0.1430(25)$ \\
$0.6162(10)$ & $0.2336(6)$ & $0.1506(24)$ \\
$0.5232(9)$ & $0.2436(6)$ & $0.0886(20)$ \\
$0.5094(9)$ & $0.3078(6)$ & $0.1346(24)$ \\
$0.4357(11)$ & $0.3379(7)$ & $0.0412(24)$ \\
$0.4355(10)$ & $0.4040(7)$ & $0.0760(26)$ \\
$0.3598(10)$ & $0.4331(6)$ & $-0.0117(23)$ \\
$0.7187(10)$ & $0.3610(6)$ & $0.3649(22)$ \\
$0.7995(10)$ & $0.3731(7)$ & $0.3038(24)$ \\
$0.8352(11)$ & $0.4277(7)$ & $0.3373(24)$ \\
$0.7909(10)$ & $0.4685(6)$ & $0.4300(23)$ \\
$0.7109(9)$ & $0.4572(7)$ & $0.4970(28)$ \\
$0.6761(9)$ & $0.4015(7)$ & $0.4669(24)$ \\
$0.6118(10)$ & $0.1591(7)$ & $0.3948(24)$ \\
$0.6957(14)$ & $0.1248(8)$ & $0.3837(31)$ \\
$0.4396(15)$ & $0.1598(8)$ & $0.0952(30)$ \\
$0.3685(12)$ & $0.1269(8)$ & $0.1991(27)$ \\
$0.3928(13)$ & $0.2885(8)$ & $-0.2215(30)$ \\
$0.4119(13)$ & $0.2830(8)$ & $-0.4125(22)$ \\
$0.4558(14)$ & $0.4642(10)$ & $0.3140(33)$ \\
$0.4498(13)$ & $0.4662(10)$ & $0.5115(38)$ \\
$0.2312(12)$ & $0.4330(7)$ & $0.1574(30)$ \\
$0.1480(11)$ & $0.4022(7)$ & $0.1803(28)$ \\
& &
\end{tabular}

$U_{\text {eq }}$

$59(2)$

$43(5)$

$37(4)$

$40(5)$

$46(5)$

$47(5)$

$68(6)$

$65(6)$

$104(9)$

$68(6)$

$31(5)$

$33(5)$

41 (7)

44 (7)

37 (7)

29 (6)

38 (7)

40 (7)

41 (7)

47 (7)

34 (6)

44 (7)

$52(7)$

42 (7)

$54(7)$

$47(7)$

51 (8)

$91(11)$

59 (9)

$82(10)$

$58(9)$

$65(9)$

$66(10)$

$108(12)$

$66(8)$

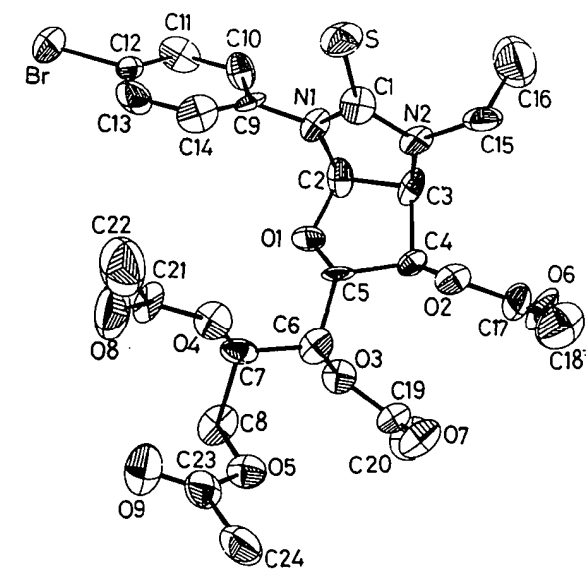

Fig. 1. An ORTEP plot (Johnson, 1965) of the molecule with atom labelling. energy over intermolecular, a habitual feature in these compounds. The ethyl group is also twisted with respect to the imidazolidine ring as indicated by the torsion angle $\mathrm{C} 1-\mathrm{N} 2-\mathrm{C} 15-\mathrm{C} 16=-78(2)^{\circ}$.

Bond lengths and angles in the furanosyl ring are close to the mean values observed for analogous compounds. The asymmetry of the endocyclic bonds $\mathrm{O} 1-\mathrm{C} 2=1.420(19)$ and $\mathrm{O} 1-\mathrm{C} 5=1.398(18) \AA$, a typical feature of these compounds due to anomeric effects, is difficult to establish in this case because of the high e.s.d.'s. In terms of the ring-puckering coordinates (Cremer \& Pople, 1975), the amplitude and phase magnitudes are $Q=0.406(16) \AA$ and $\varphi=141(2)^{\circ}$ for the sequence $\mathrm{O} 1-\mathrm{C} 2-\mathrm{C} 3-\mathrm{C} 4-\mathrm{C} 5$ and the resulting conformation is near to the puckering mode ${ }^{4} E$, as found for analogous compounds (Estrada, Conde \& Márquez, 1984, 1986; Conde, Millán, Conde \& Márquez, 1985b). The values of the pseudorotational parameters correspond to one of the zones of high population density in the conformational wheel defined in a statistical study performed over a large number of the sugar rings by Murray-Rust \& Motherwell (1978).

\section{Table 2. Bond distances $(\AA)$ and angles $\left(^{\circ}\right)$}

\begin{tabular}{|c|c|c|c|}
\hline $\mathrm{Br}-\mathrm{C} 12$ & $1.90(1)$ & $\mathrm{S}-\mathrm{Cl}$ & $1.69(2)$ \\
\hline $\mathrm{O} 1-\mathrm{C} 2$ & $1.42(2)$ & $\mathrm{O} 1-\mathrm{C} 5$ & $1.40(2)$ \\
\hline $\mathrm{O} 2-\mathrm{C} 4$ & $1.43(2)$ & $\mathrm{O} 2-\mathrm{C} 17$ & $1 \cdot 30(2)$ \\
\hline $\mathrm{O} 3-\mathrm{C} 6$ & $1.44(2)$ & O3-C19 & $1 \cdot 36(2)$ \\
\hline $\mathrm{O} 4-\mathrm{C} 7$ & $1.41(2)$ & $\mathrm{O} 4-\mathrm{C} 21$ & $1 \cdot 32(2)$ \\
\hline $\mathrm{O}-\mathrm{C} 8$ & $1.43(2)$ & $\mathrm{O} 5-\mathrm{C} 23$ & $1 \cdot 36(2)$ \\
\hline $\mathrm{O} 6-\mathrm{C} 17$ & $1 \cdot 17(3)$ & O7-C19 & $1 \cdot 18(2)$ \\
\hline $\mathrm{O} 8-\mathrm{C} 21$ & $1 \cdot 15(3)$ & $\mathrm{O} 9-\mathrm{C} 23$ & $1 \cdot 19(2)$ \\
\hline $\mathrm{N} 1-\mathrm{C} 1$ & $1.35(2)$ & $\mathrm{N} 1-\mathrm{C} 2$ & $1.43(2)$ \\
\hline $\mathrm{N} 1-\mathrm{C} 9$ & $1.43(2)$ & $\mathrm{N} 2-\mathrm{Cl}$ & $1 \cdot 34(2)$ \\
\hline $\mathrm{N} 2-\mathrm{C} 3$ & $1.45(2)$ & N2-C 15 & $1.43(2)$ \\
\hline $\mathrm{C} 2-\mathrm{C} 3$ & $1.55(2)$ & C3-C4 & $1.55(2)$ \\
\hline $\mathrm{C} 4-\mathrm{C} 5$ & $1.52(2)$ & C5-C6 & $1.52(2)$ \\
\hline $\mathrm{C} 6-\mathrm{C} 7$ & $1.53(2)$ & $\mathrm{C} 7-\mathrm{C} 8$ & $1.51(2)$ \\
\hline $\mathrm{C} 9-\mathrm{C} 10$ & $1 \cdot 37(2)$ & $\mathrm{C} 9-\mathrm{C} 14$ & $1.38(2)$ \\
\hline $\mathrm{C} 10-\mathrm{C} 11$ & $1.39(2)$ & $\mathrm{C} 11-\mathrm{C} 12$ & $1.36(2)$ \\
\hline $\mathrm{C} 12-\mathrm{C} 13$ & $1 \cdot 38(2)$ & C13-C14 & $1.40(2)$ \\
\hline $\mathrm{C} 15-\mathrm{C} 16$ & $1.53(3)$ & $\mathrm{C} 17-\mathrm{C} 18$ & $1.56(3)$ \\
\hline $\mathrm{C} 19-\mathrm{C} 20$ & $1.51(3)$ & $\mathrm{C} 21-\mathrm{C} 22$ & $1.53(4)$ \\
\hline $\mathrm{C} 23-\mathrm{C} 24$ & $1.49(2)$ & & \\
\hline $\mathrm{C} 2-\mathrm{O} 1-\mathrm{C} 5$ & $107(1)$ & $\mathrm{C} 4-\mathrm{O} 2-\mathrm{C} 17$ & $115(1)$ \\
\hline C6-O3-C19 & $119(1)$ & $\mathrm{C} 7-\mathrm{O} 4-\mathrm{C} 21$ & $116(1)$ \\
\hline $\mathrm{C} 8-\mathrm{O} 5-\mathrm{C} 23$ & $118(1)$ & $\mathrm{C} 2-\mathrm{N} 1-\mathrm{C} 9$ & $119(1)$ \\
\hline $\mathrm{Cl}-\mathrm{N} 1-\mathrm{C} 9$ & $128(1)$ & $\mathrm{C} 1-\mathrm{N} 1-\mathrm{C} 2$ & $113(1)$ \\
\hline $\mathrm{C} 3-\mathrm{N} 2-\mathrm{C} 15$ & $123(1)$ & $\mathrm{C} 1-\mathrm{N} 2-\mathrm{C} 15$ & $123(1)$ \\
\hline $\mathrm{C} 1-\mathrm{N} 2-\mathrm{C} 3$ & $111(1)$ & $\mathrm{N} 1-\mathrm{C} 1-\mathrm{N} 2$ & $110(1)$ \\
\hline $\mathrm{S}-\mathrm{C} 1-\mathrm{N} 2$ & $126(1)$ & $\mathrm{S}-\mathrm{C} 1-\mathrm{N} 1$ & $123(1)$ \\
\hline $\mathrm{O} 1-\mathrm{C} 2-\mathrm{N} 1$ & $114(1)$ & $\mathrm{N} 1-\mathrm{C} 2-\mathrm{C} 3$ & $102(1)$ \\
\hline $\mathrm{O} 1-\mathrm{C} 2-\mathrm{C} 3$ & $107(1)$ & $\mathrm{N} 2-\mathrm{C} 3-\mathrm{C} 2$ & $104(1)$ \\
\hline $\mathrm{C} 2-\mathrm{C} 3-\mathrm{C} 4$ & $102(1)$ & $\mathrm{N} 2-\mathrm{C} 3-\mathrm{C} 4$ & $112(1)$ \\
\hline $\mathrm{O} 2-\mathrm{C} 4-\mathrm{C} 3$ & $114(1)$ & $\mathrm{C} 3-\mathrm{C} 4-\mathrm{C} 5$ & $102(1)$ \\
\hline $\mathrm{O} 2-\mathrm{C} 4-\mathrm{C} 5$ & $110(1)$ & $\mathrm{O} 1-\mathrm{C} 5-\mathrm{C} 4$ & $103(1)$ \\
\hline $\mathrm{C} 4-\mathrm{C} 5-\mathrm{C} 6$ & $115(1)$ & $\mathrm{O} 1-\mathrm{C} 5-\mathrm{C} 6$ & $109(1)$ \\
\hline $\mathrm{O} 3-\mathrm{C} 6-\mathrm{C} 5$ & $111(1)$ & $\mathrm{C} 5-\mathrm{C} 6-\mathrm{C} 7$ & $111(1)$ \\
\hline $\mathrm{O} 3-\mathrm{C} 6-\mathrm{C} 7$ & $107(1)$ & $\mathrm{O} 4-\mathrm{C} 7-\mathrm{C} 6$ & $107(1)$ \\
\hline $\mathrm{C} 6-\mathrm{C} 7-\mathrm{C} 8$ & $111(1)$ & $\mathrm{O} 4-\mathrm{C} 7-\mathrm{C} 8$ & $111(1)$ \\
\hline $\mathrm{O} 5-\mathrm{C} 8-\mathrm{C} 7$ & $113(1)$ & $\mathrm{N} 1-\mathrm{C} 9-\mathrm{C} 14$ & $121(1)$ \\
\hline $\mathrm{N} 1-\mathrm{C} 9-\mathrm{C} 10$ & $119(1)$ & $\mathrm{C} 10-\mathrm{C} 9-\mathrm{C} 14$ & $120(1)$ \\
\hline $\mathrm{C} 9-\mathrm{C} 10-\mathrm{C} 11$ & $119(1)$ & $\mathrm{C} 10-\mathrm{C} 11-\mathrm{C} 12$ & $120(1)$ \\
\hline $\mathrm{Br}-\mathrm{C} 12-\mathrm{C} 11$ & $120(1)$ & $\mathrm{C} 11-\mathrm{C} 12-\mathrm{C} 13$ & $122(1)$ \\
\hline $\mathrm{Br}-\mathrm{C} 12-\mathrm{C} 13$ & $117(1)$ & $\mathrm{C} 12-\mathrm{Cl}_{13}-\mathrm{C} 14$ & $117(1)$ \\
\hline $\mathrm{C} 9-\mathrm{C} 14-\mathrm{C} 13$ & $121(1)$ & $\mathrm{N} 2-\mathrm{C} 15-\mathrm{C} 16$ & $112(1)$ \\
\hline $\mathrm{O} 2-\mathrm{C} 17-\mathrm{O} 6$ & $128(2)$ & $\mathrm{O} 6-\mathrm{C} 17-\mathrm{C} 18$ & $121(2)$ \\
\hline $\mathrm{O} 2-\mathrm{C} 17-\mathrm{C} 18$ & $110(2)$ & $\mathrm{O} 3-\mathrm{C} 19-\mathrm{O} 7$ & $121(2)$ \\
\hline $\mathrm{O} 7-\mathrm{C} 19-\mathrm{C} 20$ & $127(2)$ & $\mathrm{O} 3-\mathrm{C} 19-\mathrm{C} 20$ & $112(1)$ \\
\hline $\mathrm{O} 4-\mathrm{C} 21-\mathrm{O} 8$ & $128(2)$ & $\mathrm{O} 8-\mathrm{C} 21-\mathrm{C} 22$ & $122(2)$ \\
\hline $\mathrm{O} 4-\mathrm{C} 21-\mathrm{C} 22$ & $110(2)$ & $\mathrm{O} 5-\mathrm{C} 23-\mathrm{O} 9$ & $122(2)$ \\
\hline $\mathrm{O} 9-\mathrm{C} 23-\mathrm{C} 24$ & $126(2)$ & $\mathrm{O} 5-\mathrm{C} 23-\mathrm{C} 24$ & $111(1)$ \\
\hline
\end{tabular}


The asymmetry parameter of Nardelli (1983), $\Delta C_{s^{-}}$ $(C 5)=0.012(9)$, indicates approximate mirror symmetry in the ring. The small value of the torsion angle $\mathrm{O} 1-\mathrm{C} 2-\mathrm{C} 3-\mathrm{C} 4=0.9(16)^{\circ}$, a typical feature of these compounds, may be attributed to the distortion of the furanose group on its fusion with the imidazolidine ring. The two fused rings in the bicyclic system show a cis form of coupling and the bonds at C2 and $\mathrm{C} 3$ are nearly eclipsed, these features being similar to those observed for analogous compounds. The dihedral angle between the least-squares planes through the imidazolidine and furanose rings is $71.5(7)^{\circ}$.

\section{Crystal-packing analysis}

The crystal cohesion is due mainly to van der Waals forces. Only the interactions $\mathrm{C} 10-\mathrm{H} 10 \cdots \mathrm{O} 7\left(\frac{1}{2}+x\right.$, $\left.\frac{1}{2}-y,-z\right)$ and $\mathrm{C} 24-\mathrm{H} 242 \cdots \mathrm{O} 6\left(-\frac{1}{2}+x, \frac{1}{2}-y,-z\right)$, linking molecules related by a screw axis parallel to [100], may be considered as weak hydrogen bonds. Details of the geometry of these contacts are: $\mathrm{C} 10-$ $\mathrm{H} 10=1.08$ (18), $\mathrm{C} 10 \cdots 07=3.41$ (2), $\mathrm{H} 10 \cdots \mathrm{O} 7=$ $2.47(17) \AA, \quad \mathrm{C} 10-\mathrm{H} 10 \cdots \mathrm{O} 7=145(14)^{\circ} ; \quad \mathrm{C} 24-$ $\mathrm{H} 242=1.08(20), \quad \mathrm{C} 24 \cdots \mathrm{O} 6=3.23(2), \mathrm{H} 242 \cdots \mathrm{O} 6$ $=2.54(20) \AA, \mathrm{C} 24-\mathrm{H} 242 \cdots \mathrm{O} 6=121(14)^{\circ}$. As observed, the $\mathrm{H} \cdots \mathrm{O}$ distances of these contacts are, respectively, 0.23 and $0.16 \AA$ below the sum of the van der Waals radii of $\mathrm{H}$ and $\mathrm{O}(1.20$ and $1.50 \AA)$ and the angle $\mathrm{C}-\mathrm{H}-\mathrm{O}$ is lower for the longer contact but appreciably above the accepted limit of $90^{\circ}$ for the C-H...O hydrogen bonds (Taylor \& Kennard, 1982), so they can be considered as hydrogen bonds.

A minimization of the crystal lattice energy with respect to lattice constants, molecular translation and rotation and also subrotation of molecular fragments about selected bonds as axes was performed by means of the program PCK6 (Williams, 1972b, 1974) starting from the experimental structure. Potential-energy functions in the form $U(r)=-A r^{-6}+B \exp (-C r)$ were used to represent the non-bonded interatomic potential energy. For runs including Coulombic interactions the atomic residual charges were empirically estimated (Skorczyk, 1976). The set of potential parameters included parameters fitted by Williams $(1972 a)$ for $\mathrm{C} \cdots \mathrm{C}$ and $\mathrm{H} \cdots \mathrm{H}$ interactions, by Govers (1975) for $\mathrm{N} \cdots \mathrm{N}$, by Mason \& Kreevoy (1955) for $\mathrm{O} \cdots \mathrm{O}$ and S...S and parameters of Burgos \& Bonadeo (1977) for $\mathrm{Br} \cdots \mathrm{Br}$. For mixed interactions, combination rules of Mirskaya (1973) were used. Three runs of energy minimization were carried out for both $\exp (-6)$ and $\exp (-6-1)$ potential functions: in the first, the X-ray molecular structure was retained and the lattice constants were fixed; in the second, cell parameters were included as variables and, finally, five subrotations about selected bonds as axes were relaxed.

Representative results of energy minimization are given in Table 3 in which changes (\%) of lattice parameters, translation of centre of mass, overall molecular rotation and changes in relaxed torsion angles are shown. The calculated value for lattice energy, not included in Table 3 , should be higher than the experimental one because of the representation of the intermolecular hydrogen bonds by van der Waals potential functions. However, in spite of the lack of significance for the calculated values of the lattice energy, the Coulombic term is found to make an appreciable contribution (40\%) to the lattice energy, in agreement with previous results on analogous compounds. As shown in Table 3, the inclusion of the cell parameters as variables leads to an expansion along a and $\mathbf{b}$ and a contraction along $\mathbf{c}$ with a cell volume expansion slightly higher for runs not including the Coulombic term. When molecular flexibility (subrotations) is incorporated an appreciably lower volume expansion is found.

Apart from this effect, the theoretical configuration agrees with the experimental structure. The optimized structure remains very similar with regard to the molecular parameters as shown in Table 3: shifts of the

\section{Table 3. Molecular-packing analysis}

(a) With cell parameters and torsions fixed at experimental values; (b) with optimized cell parameters and torsions fixed; (c) with optimized cell parameters and torsions relaxed.

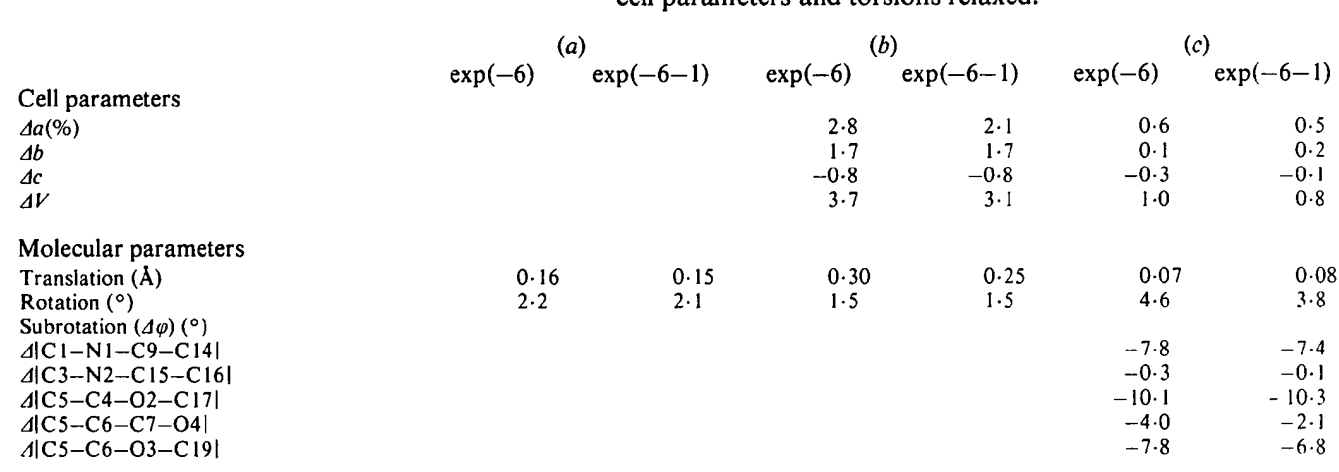


positional molecular parameters are lower when molecular flexibility is included, but a higher value of the overall molecular rotation is observed in this case. The torsional angles of selected molecular fragments show in some cases (the ethyl group and two of the acetyl chains) a larger deviation for the experimental values but inclusion of the Coulombic term does not appreciably improve the fit. These discrepancies between experimental and theoretical parameters of molecular subrotations and the above-cited cell expansion could be attributed to limitations of the force-field approach, in particular the assumed transferability of potential parameters.

The authors thank Professor J. A. Galbis-Pérez for supplying the crystals and for helpful discussion on chemical aspects and Professor A. López-Castro for collecting the diffractometer data. The present work is part of a research project supported by the CAICYT of the Spanish Government.

\section{References}

Burgos, E. \& Bonadeo, H. (1977). Chem. Phys. Lett. 49, $475-478$.

Conde, C. F., Millán, M., Conde, A. \& Márquez, R. (1985a). Acta Cryst. C41, 277-280.

Conde, C. F., Millán, M., Conde, A. \& Márquez, R. (1985b). Acta Cryst. C41, 1658-1662.
Cremer, D. \& Pople, J. A. (1975). J. Am. Chem. Soc. 97, 1354-1358.

Estrada, M. D., Conde, A. \& Márquez, R. (1983). Acta Cryst. C39, 1418-1421.

Estrada, M. D., Conde, A. \& MÁrquez, R. (1984). Acta Cryst. C40, 898-901.

EstradA, M. D., Conde, A. \& MÁRquez, R. (1986). Acta Cryst. C42, 454-457.

Galbis-Pérez, J. A., Palacios-Albarrán, J. C., JiménezRequejo, J. L. \& Avalos-GonzÁlez, M. (1984). Carbohydr. Res. 129, 131-142.

Govers, H. A. J. (1975). Acta Cryst. A31, 380-385.

Hamilton, W. C. (1959). Acta Cryst. 12, 609-601.

International Tables for X-ray Crystallography (1974). Vol. IV. Birmingham: Kynoch Press. (Present distributor D. Reidel, Dordrecht.)

JoHNSON, C. K. (1965). ORTEP. Report ORNL-3794. Oak Ridge National Laboratory, Tennessee.

Mason, A. \& Kreevoy, M. M. (1955). J. Am. Chem. Soc. 77, 5808-5814.

MiRSKAYA, K. V. (1973). Tetrahedron, 29, 679-682.

Murray-Rust, P. \& Motherwell, S. (1978). Acta Cryst. B34, 2534-2546.

NARDELLI, M. (1983). Acta Cryst. C39, 1141-1142.

SkORCZYCK, R. (1976). Acta Cryst. A32, 447-452.

Stewart, J. M., Machin, P. A., Dickinson, C. W., Ammon, H. L., HeCK, H. \& FlaCK, H. (1976). The XRAY76 system. Tech. Rep. TR-446. Computer Science Center, Univ. of Maryland, College Park, Maryland.

Taylor, R. \& Kennard, O. (1982). J. Am. Chem. Soc. 104, 5063-5070.

Williams, D. E. (1972a). Acta Cryst. A28, 84-88.

Williams, D. E. (1972b). Acta Cryst. A28, 629-635.

Williams, D. E. (1974). Acta Cryst. A30, 71-77.

Acta Cryst. (1987). C43, 1138-1142

\title{
Structure of 5-( $\beta$-D-Glucopyranosyl)barbituric Acid Trihydrate*
}

\author{
By M. Millan, C. F. Conde, A. Conde and R. Márquez \\ Departamento de Optica y Sección de Física del Centro Coordinado del CSIC, Universidad de Sevilla, Spain
}

(Received 17 September 1985; accepted 6 January 1987)

\begin{abstract}
C}_{10} \mathrm{H}_{15} \mathrm{~N}_{3} \mathrm{O}_{7} \cdot 3 \mathrm{H}_{2} \mathrm{O}, M_{r}=343 \cdot 3$, monoclinic, $P 2_{1}, \quad a=10.883(3), \quad b=12.497(20), \quad c=$ $10.553(4) \AA, \beta=91.05(3)^{\circ}, V=1435$ (2) $\AA^{3}, Z=4$, $D_{m}=1.57(2), \quad D_{x}=1.589 \mathrm{Mg} \mathrm{m}^{-3}, \quad$ Mo $K \alpha, \quad \lambda=$ $0.7107 \AA, \mu=0.13 \mathrm{~mm}^{-1}, F(000)=728, T=300 \mathrm{~K}$, $R=0.064$ for 2692 observed independent reflexions. The compound presents a zwitterionic structure in which the negative charge is delocalized in the system formed by the two carbonyl groups at $\mathrm{C} 4$ and $\mathrm{C} 6$ and the carbon atom $\mathrm{C} 5$ of the barbituric ring. In the two independent molecules in the asymmetric unit the pyranose ring adopts a ${ }^{4} C_{1}$ conformation and the dihedral angles between the pyranose and barbituric
\end{abstract}

* Barbituric acid is $2,4,6(1 H, 3 H, 5 H)$-pyrimidinetrione. 0108-2701/87/061138-05\$01.50 rings for the two molecules are 80.9 (3) and $90.3(3)^{\circ}$. The molecules are linked by an extensive threedimensional hydrogen-bonding network, involving the water hydration molecules, which stabilize the crystal structure.

Introduction. The structure determination of the title compound (II) was undertaken as part of a continuing project on conformational details of $C$-nucleosides in the solid state. An easy synthesis of $C$-nucleoside derivatives of barbituric acids by reaction of aldoses with the barbituric acid has been reported (AvalosGonzález, 1981; Galbis-Pérez, Avalos-González, Jiménez-Requejo \& Palacios-Albarrán, 1983). In this way, the reaction of barbituric acid with D-glucose (c) 1987 International Union of Crystallography 